\title{
Bacterial Succession in Karst Calcareous Soils Derived from Different Development Stages in Southwest China
}

\author{
Yueming Liang ${ }^{1,3}$, Fujing Pan ${ }^{2 *}$, Jianhua Cao ${ }^{1,3,4}$, Meina Zhu ${ }^{1,3}$, Chang Liu ${ }^{2}$, \\ Ang Song ${ }^{1,3}$, Qiang Li ${ }^{1,3 * *}$ \\ ${ }^{1}$ Key Laboratory of Karst Dynamics, Ministry of Land and Resources \& Guangxi Zhuangzu Autonomy Region, \\ Institute of Karst Geology, Chinese Academy of Geological Sciences, Guilin, 541004, China \\ ${ }^{2}$ College of Environmental Science and Engineering, Guilin University of Technology, Guilin, 541004, China \\ ${ }^{3}$ International Research Center on Karst under the Auspices of UNESCO, Guilin, 541004, China \\ ${ }^{4}$ National Center for International Research, Guilin, 541004, China
}

Received: 19 June 2020

Accepted: 15 October 2020

\begin{abstract}
It is known that soils derived from different parent materials drive the distinct bacterial community structures, however, the influence of soils derived from the same soil parent material in different development stages of karst on the microbial diversity are unknown. In this study, three calcareous soils (including yellow, red and black calcareous soils) derived from different development stages in karst shrub ecosystems were collected at five profile layers up to $100 \mathrm{~cm}$ deep, and were determined bacterial communities by using Illumina amplicon sequencing and quantitative polymerase chain reaction (qPCR) techniques. The results showed that Proteobacteria, Firmicutes, Acidobacteria, Chloroflexi, and Verrucomicrobia dominated the calcareous soils from karst shrub ecosystems. The relative abundances of Proteobacteria and Firmicutes increased with the increasing profile depth in three calcareous soils, while Acidobacteria and Verrucomicrobia were opposite. The diversities of bacterial communities in topsoil layers at $0 \sim 40 \mathrm{~cm}$ depths were higher than those of layers below $40 \mathrm{~cm}$ deep, but became similar at depths below $40 \mathrm{~cm}$. The bacterial community structures differed among three calcareous soils, and were different between the surface layers and the other layers in all soils. The abundance and structure of bacteria was strongly related to soil organic carbon, suggesting their importance for carbon cycle. Path analysis showed that soil bacterial community structure can be directly influenced by calcareous soil type, and indirectly impacted by soil depths through soil properties. Our findings revealed that calcareous soil type was an important factor in determining soil bacterial community structure, and bacterial succession was closely related to the formation of calcareous soil in karst regions.
\end{abstract}

Keywords: calcareous soils, Illumina sequencing, microbial community, soil profile, soil type

\footnotetext{
*e-mail: panfujing@glut.edu.cn
}

**e-mail: glqiangli@hotmail.com 


\section{Introduction}

Karst region, approximately cover $12 \%$ of the Earth's land surface, and cover $550,000 \mathrm{~km}^{2}$ in Southwest China [1]. The ecosystem in this region is fragile due to its unique characteristics (soluble rock, caves, sinkhole and mogotes, etc.). Soils in this region are shallow, and are characterized by high calcium (Ca) and magnesium (Mg) concentrations. The high dose $\mathrm{Ca}$ easily stabilizing karst soil organic matter [2] might result in the low decomposing rate of soil organic matter (SOM). This reduces the release of release carbon, nitrogen, and phosphorus. Knowing that soil microbes control the mineralization rate of SOM and play a key role in nutrition cycles. However, information on the importance of soil bacterial communities in the nutrition cycles of karst region is less well understood.

Currently, calcareous soils are classified as Chromic Luvisol and developed from carbonate weathering. Calcareous soils mainly distributed in subtropical karst region (about 907 thousand $\mathrm{km}^{2}$ in southwest China) [3], which is characterized by high rainfall and high leaching strength. This type soil is divided into several soil subgroups according to their development stages, such as black, yellow, and red calcareous soil. A previous study indicated that the formation of different calcareous soil was closely related to leaching [4]. Calcareous soils derive from carbonatites firstly forms a thin black calcareous soil (approximately $20 \mathrm{~cm}$ ), and then forms yellow calcareous soil and ultimately red calcareous soil after leaching. A previous study in karst region has reported that soil physicochemical characteristics, including soil $\mathrm{pH}$ and mineral composition, significantly differ among calcareous soils [4]. Because physicochemical characteristics are strongly linked to bacterial communities [5-8], we hypothesized that bacterial community structure exhibited disparate among calcareous soils derived from different development stages in karst regions.

Considering the distribution of soil bacteria in different soil depths and soil types, it is helpful to fully identify the role of bacteria in a given ecosystem. Although the soil profiles are often many meters deep, we cannot think that the bacterial communities dwell in subsurface horizons were simply diluted analogs of the surface bacterial communities. The function of bacteria should be fundamentally similar between the surface and subsurface horizons. In fact, the variety in composition and function of bacterial community across profile were well confirmed in the previous studies. For example, Zhang et al. found that bacterial diversity was typically higher in surface horizons than that in the deepest horizon from semiarid grassland in China [9]. Yan et al. found that Proteobacteria [5], considering R-strategists, dominated in the soil surface, while Acidobacteria considering K-strategists, distributed more in the soil subsurface. The above studies suggested that soil depth can directly affect bacterial communities by changing their resources and habitat [10] and/or indirectly influence bacterial communities through different $\mathrm{pH}$ values [11-13] and physicochemical characteristics [6, 14]. However, for a given ecosystem, factors influencing soil bacterial communities may differ from other ecosystem, for example karst ecosystem with less information about the relationship between bacterial communities and soil/environment factor across soil profile.

Soil type and depth exert great effect on the bacterial communities. However, few studies have synchronously explored the relationships among soil type, soil depth and bacterial communities, and some results are somewhat contradictory. For example, Van et al. found that the effect of soil type on the community is greater than the effect of soil depth [15]. However, Bai et al. found that soil depth had a greater effect on community composition than soil type did [10]. Such discrepancies may be related to the interactive effect of soil types and ecosystem types. Therefore, more attention is required to study the effects of soil type and soil depth on the microbial community. In this study, bacterial community structures from three calcareous soil types [yellow calcareous soil (YCS), red calcareous soil (RCS) and black calcareous soil (BCS)] (WRB Soil Taxonomy) from the karst shrub ecosystem in Guangxi, China, were studied, and the bacterial community structures were also studied across the profiles of two typical soil types.

\section{Materials and Methods}

\section{Site Descriptions and Soil Sampling}

Three calcareous soils were selected from the shrub ecosystem of the Guangxi Autonomous Region of Southwest China. YCS was collected from Baise County $\left(24^{\circ} 42^{\prime} \mathrm{N}, 106^{\circ} 30^{\prime} \mathrm{E}\right)$, RCS was collected from Laibin County $\left(23^{\circ} 25^{\prime} \mathrm{N}, 109^{\circ} 3^{\prime} \mathrm{E}\right)$, and BCS was collected from Guilin County $\left(25^{\circ} 14^{\prime} \mathrm{N}, 110^{\circ} 20^{\prime} \mathrm{E}\right)$. These soils were classified as Chromic Luvisol. The dominant species in the shrub YCS were Rosa cymosa, Rosa roxburghii, and Pyracantha fortuneana. The dominant species in the shrub RCS were Rhodomyrtus tomentosa, Loropetalum chinense, and Paeonia delavayi. The dominant species in the shrub BCS were Loropetalum chinense, Alchornea trewioides, and Bauhinia championii. The dominant species of the selected sites, which were farmlands that had been abandoned for 15-20 years, were replaced by shrubs in secondary autogenic succession with minimal anthropogenic disturbance.

Soil samples were collected in November 2015. Each shrub plot was $10 \mathrm{~m} \times 10 \mathrm{~m}$ in size, and 15 shrub plots (i.e., five reduplicate yellow calcareous plots, six reduplicate red calcareous plots, and four reduplicate black calcareous plots) were established. For one plot, 12 soil cores $(0-20 \mathrm{~cm}$ depth) were collected and thoroughly mixed to form one composite soil 
sample. Fifteen topsoil samples (i.e., five reduplicate YCS samples + six reduplicate RCS samples + four reduplicate BCS samples) were collected from the shrub ecosystem. In each plot, a profile was prepared, and each profile was $0.5 \mathrm{~m}$ wide and $1 \mathrm{~m}$ deep. The profile was sampled by taking five separate subsamples at each of the following depths: $0-20 \mathrm{~cm}, 20-40 \mathrm{~cm}, 40-60 \mathrm{~cm}$, $60-80 \mathrm{~cm}$ and $80-100 \mathrm{~cm}$. Fifty-five soil subsamples were collected $[2$ soils $(Y C S$ and RCS) $\times 5$ depths $\times 11$ replicates (5 YCS samples +6 RCS samples)]. In total, 70 soil samples were collected from the shrub ecosystem. It is worth mentioning that black calcareous soil can only form a thin layer (approximately $20 \mathrm{~cm}$ ) and thus cannot collect profile samples. Each soil sample was divided into two portions. An approximately $50 \mathrm{~g}$ soil sample was immediately frozen in liquid nitrogen and transported to the laboratory for molecular analysis. The other portion was air-dried for analysis of its physicochemical properties. Soil samples were labelled YCS-RCS-BCS1 $(0-20 \mathrm{~cm})$, YCS-RCS-BCS2 $(20-40 \mathrm{~cm})$, YCS-RCS-BCS3 (40-60 cm), YCS-RCSBCS4 $(60-80 \mathrm{~cm})$ and YCS-RCS-BCS5 (80-100 cm).

\section{Soil Physicochemical Properties}

Soil $\mathrm{pH}$ values were determined with a soil:water ratio of 1:2.5 (w/v) using a $\mathrm{pH}$ meter (Delta 320; MettlerToledo Instruments Ltd., Shanghai, China). Available phosphorus (AP) was extracted with $0.5 \mathrm{M}$ sodium bicarbonate and analysed using the Mo-Sb colorimetric method [16]. Soil organic carbon (SOC) was measured using $\mathrm{K}_{2} \mathrm{Cr}_{2} \mathrm{O}_{7}-\mathrm{H}_{2} \mathrm{SO}_{4}$ oxidation-reduction titration, and total nitrogen (TN) was measured with a FIAstar (FIAstar 5000 FOSS, Sweden Ltd) using the Kjeldahl method [17]. Total phosphorus (TP) was determined by acid digestion with an $\mathrm{H}_{2} \mathrm{SO}_{4}+\mathrm{HClO}_{4}$ solution. The soil physicochemical properties are summarized in Table 1.

\section{DNA Extraction, Quantitative Analysis of 16S rRNA Genes, and Pyrosequencing}

DNA was extracted from $0.5 \mathrm{~g}$ of fresh soil using the Fast DNA Spin Kit (MP Biomedicals, Carlsbad, CA, USA) following the manufacturer's instructions. The extracted DNA was dissolved in $50 \mu \mathrm{L}$ of sterilized water. The DNA concentration was determined using a spectrophotometer (NanoDrop; PeqLab, Erlangen, Germany), and DNA samples were then stored at $-20^{\circ} \mathrm{C}$ until further analysis.

Quantitative polymerase chain reaction (qPCR; BioRad, CA, USA) was used to measure the abundance of 16S rRNA genes by using the F338/R518 primers. The reaction volume was $25 \mu \mathrm{L}$ and contained $12.5 \mu \mathrm{L}$ of Green-2-Go Master Mix (Sangon Biotech, Shanghai, China), $1 \mu \mathrm{L}$ of each primer (Sangon Biotech, China), $1 \mu \mathrm{L}$ of DNA template (diluted to $5 \mathrm{ng} \mu \mathrm{L}^{-1}$ using sterile water), and $9.5 \mu \mathrm{L}$ of sterilized water. The thermal cycling protocol was as follows: $3 \mathrm{~min}$ at $95^{\circ} \mathrm{C}$; 30 cycles of $45 \mathrm{~s}$ at $95^{\circ} \mathrm{C}, 30 \mathrm{~s}$ at $56^{\circ} \mathrm{C}$, and $30 \mathrm{~s}$ at $72^{\circ} \mathrm{C}$; and a final elongation step at $72^{\circ} \mathrm{C}$ for $1 \mathrm{~min}$.

A plasmid containing a partial fragment of $16 \mathrm{~S}$ rRNA genes was used to generate a standard curve

Table 1. Selected soil physicochemical properties of the test soils.

\begin{tabular}{|c|c|c|c|c|c|c|c|}
\hline & & Texture & SOC g kg-1 & AP mg kg-1 & $\mathrm{pH}$ & $\mathrm{TN} \mathrm{g} \mathrm{kg}^{-1}$ & $\mathrm{TP} \mathrm{kg}^{-1}$ \\
\hline YCS & Topsoil & Clay & $31.71 \pm 9.37 \mathrm{ab}$ & $8.39 \pm 1.99 \mathrm{a}$ & $6.48 \pm 0.98 \mathrm{a}$ & $1.87 \pm 0.55 \mathrm{a}$ & $0.43 \pm 0.16 \mathrm{ab}$ \\
\hline & $0-20 \mathrm{~cm}$ & & $23.54 \pm 7.43 \mathrm{~A}$ & $4.25 \pm 0.60 \mathrm{~A}$ & $6.39 \pm 0.54 \mathrm{~A}$ & $1.62 \pm 0.36 \mathrm{~A}$ & $0.18 \pm 0.03 \mathrm{~A}$ \\
\hline & $20-40 \mathrm{~cm}$ & & $15.60 \pm 5.30 \mathrm{AB}$ & $3.389 \pm 0.61 \mathrm{AB}$ & $6.39 \pm 0.60 \mathrm{~A}$ & $1.19 \pm 0.32 \mathrm{AB}$ & $0.17 \pm 0.05 \mathrm{~A}$ \\
\hline & $40-60 \mathrm{~cm}$ & & $8.45 \pm 3.16 \mathrm{~B}$ & $2.59 \pm 0.61 \mathrm{AB}$ & $6.51 \pm 0.56 \mathrm{~A}$ & $0.76 \pm 0.25 \mathrm{~B}$ & $0.14 \pm 0.04 \mathrm{~A}$ \\
\hline & $60-80 \mathrm{~cm}$ & & $6.27 \pm 2.51 \mathrm{~B}$ & $2.15 \pm 0.43 \mathrm{~B}$ & $6.56 \pm 0.52 \mathrm{~A}$ & $0.66 \pm 0.18 \mathrm{~B}$ & $0.17 \pm 0.04 \mathrm{~A}$ \\
\hline & $80-100 \mathrm{~cm}$ & & $5.21 \pm 1.88 \mathrm{~B}$ & $1.77 \pm 0.48 \mathrm{~B}$ & $6.67 \pm 0.49 \mathrm{~A}$ & $0.48 \pm 0.16 \mathrm{~B}$ & $0.09 \pm 0.01 \mathrm{~A}$ \\
\hline RCS & Topsoil & Clay & $12.54 \pm 4.02 \mathrm{~b}$ & $2.69 \pm 0.48 \mathrm{~b}$ & $4.72 \pm 0.43 \mathrm{~b}$ & $0.55 \pm 0.21 \mathrm{~b}$ & $0.25 \pm 0.08 \mathrm{~b}$ \\
\hline & $0-20 \mathrm{~cm}$ & & $9.33 \pm 3.19 \mathrm{~A}$ & $4.12 \pm 0.81 \mathrm{~B}$ & $4.71 \pm 0.34 \mathrm{~A}$ & $0.55 \pm 0.14 \mathrm{~A}$ & $0.16 \pm 0.08 \mathrm{~A}$ \\
\hline & $20-40 \mathrm{~cm}$ & & $6.78 \pm 1.72 \mathrm{AB}$ & $2.01 \pm 0.27 \mathrm{~B}$ & $4.92 \pm 0.63 \mathrm{~A}$ & $0.43 \pm 0.08 \mathrm{AB}$ & $0.11 \pm 0.03 \mathrm{~A}$ \\
\hline & $40-60 \mathrm{~cm}$ & & $4.55 \pm 0.60 \mathrm{AB}$ & $1.41 \pm 0.26 \mathrm{~B}$ & $4.94 \pm 0.64 \mathrm{~A}$ & $0.35 \pm 0.10 \mathrm{AB}$ & $0.08 \pm 0.03 \mathrm{~A}$ \\
\hline & $60-80 \mathrm{~cm}$ & & $3.44 \pm 0.71 \mathrm{~B}$ & $2.03 \pm 0.68 \mathrm{~B}$ & $5.16 \pm 0.63 \mathrm{~A}$ & $0.24 \pm 0.04 \mathrm{~B}$ & $0.17 \pm 0.03 \mathrm{~A}$ \\
\hline & $80-100 \mathrm{~cm}$ & & $2.97 \pm 0.61 \mathrm{~B}$ & $1.42 \pm 0.51 \mathrm{~B}$ & $5.43 \pm 0.61 \mathrm{~A}$ & $0.15 \pm 0.02 \mathrm{~B}$ & $0.16 \pm 0.05 \mathrm{~A}$ \\
\hline & Topsoil & Clay & $33.27 \pm 2.36 \mathrm{a}$ & $3.75 \pm 0.32 \mathrm{~b}$ & $5.81 \pm 0.17 \mathrm{ab}$ & $1.77 \pm 0.19 \mathrm{a}$ & $0.79 \pm 0.11 \mathrm{a}$ \\
\hline
\end{tabular}

SOC soil organic carbon, AP available phosphorus, TN total nitrogen, TP total phosphorus.

Values are the means of replicates with their associated standard errors; means in a column with the same lowercase letters are not significantly different at the $p<0.05$ level in different soil types; means in a column with the same capital letters are not significantly different at the $p<0.05$ level along the profile in the same soil type.

The values of $0-20,20-40,40-60,60-80$, and $80-100 \mathrm{~cm}$ indicate the sampling depth in the profile. 
(ranging from $10^{2}$ to $10^{8}$ copies $\mu \mathrm{L}^{-1}$ ). The average value and standard error were calculated from four replicate quantitative PCR results. Data analysis was performed automatically using the SDS 2.3 software included with the real-time PCR system. The efficiency of the reaction was $99 \%$ for 16 SrRNA genes. The $R^{2}$ value for the standard curve was greater than 0.99 , and one sharp peak was observed.

For Illumina amplicon sequencing, the primers 515F (5'-GTGCCAGCMGCCGCGGTAA-3') and 907R (5'- CCGTCAATTCMTTTRAGTTT-3') were used to amplify the V4-V5 region of the 16S rRNA genes. PCR was performed in a total volume of $50 \mu \mathrm{L}$ containing $60 \mathrm{ng}$ of template DNA, $25 \mu \mathrm{L}$ of $2 \times$ Premix Taq (TaKaRa Biotechnology Co., Dalian, China), and $0.1 \mu \mathrm{M}$ each forward and reverse primer. Thermal cycling was conducted in a Bio-Rad S1000 Cycler (Bio-Rad Laboratory, CA, USA) as follows: $94^{\circ} \mathrm{C}$ for 5 min, followed by 30 cycles of $94^{\circ} \mathrm{C}$ for $30 \mathrm{~s}, 52^{\circ} \mathrm{C}$ for $30 \mathrm{~s}$, and $72^{\circ} \mathrm{C}$ for $30 \mathrm{~s}$, and a final elongation step at $72^{\circ} \mathrm{C}$ for $10 \mathrm{~min}$. The PCR products were purified using an EZNA Gel Extraction Kit (Omega, USA). Equal amounts of the purified PCR products were sent to MAGIENE (Guangzhou, China) for pyrosequencing analysis on an Illumina HiSeq 2500 sequencer.

\section{Processing of Illumina Amplicon Sequencing Data}

Barcodes were used to assign sequences to samples that were then quality trimmed using the Trimmomatic program, version V8.0.1517. Low-quality sequences $(<150 \mathrm{bp}$ in length with an average quality score of $<30)$ were excluded from further analyses. The trimmed and unique sequences were used to define operational taxonomic units (OTUs) at the 97\% similarity level. The most abundant sequence in each OTU cluster was selected as a representative sequence and aligned using the PyNAST method [18]. A taxonomic assignment of OTUs was obtained by using the Ribosomal Database Project (RDP) pyrosequencing pipeline (http://pyro.cme. msu.edu/). The accuracy of the classifier results was obtained by comparing our representative sequences with the NCBI nucleotide database (http://blast.ncbi. nlm.nih.gov). Alpha-diversity analysis (observed OTU richness, Chaol estimator and Shannon index) was carried out in QIIME on rarefied OTU tables. To avoid biases due to different sequencing depths, OTU tables were rarefied to the lowest number of sequences per sample $(80,574)$. All of the sequences have been deposited in the GenBank short-read archive under the accession number SRP126987.

\section{Statistical Analyses}

Statistical analyses were performed in SPSS 19.0 for Windows (SPSS Inc., Chicago, IL, USA). Differences at the $p<0.05$ level were considered statistically significant based on the least significant difference (LSD) test through SPSS 19.0. Data were $\log _{(x+1)}$-transformed without being normally distributed. Two non-parametric multivariate statistical tests of dissimilarity (Adonis and multi-response permutation procedures, MRPP) were used to tests the dissimilarity of communities of bacteria between soil types using the 'vegan' package in $\mathrm{R}$ statistical software. The relationships between microbial abundance and environmental factors were evaluated using a Pearson correlation analysis. Redundancy analysis (RDA) was used to analyse the effects of soil physicochemical characteristics on microbial community composition. Prior to the RDA, a preliminary detrended correspondence analysis (DCA) showed that a linear response was appropriate for analysing the pyrosequencing data (gradient length $<3$ ). Monte Carlo permutation tests were used to assess whether the selected explanatory variable was statistically significant with 999 unrestricted permutations. Path analysis (plspm package with R) was used to investigate the direct and indirect effects of soil properties on bacterial composition.

\section{Results}

\section{Real-time PCR Estimates of Bacterial Abundances}

The bacterial abundances of the 70 soil samples were determined by real-time PCR. The abundances ranged from $0.28 \times 10^{9}$ copy/ ( $g$ dry soil) to $9.18 \times 10^{9}$ copy/ (g dry soil) (Table 2). The bacterial abundance was the highest in YCS, followed by RCS and BCS, and decreased with profile depth. Pearson analysis indicated that the bacterial abundance was positively correlated with SOC $(r=0.758, p=0.0001)$, AP ( $\mathrm{r}=0.649$, $p=0.0001), \mathrm{TN}(\mathrm{r}=0.725, p=0.0001)$ and TP $(\mathrm{r}=0.341, p=0.004)$.

\section{Taxonomic Classification and Abundance}

A total of 7,670,963 quality sequences were obtained from the 70 samples. Specifically, 5,767-119,493 sequences were obtained per sample (mean 109,585; Table 2). The read lengths ranged from 337 to $418 \mathrm{bp}$, with a mean of 373 bp. Over $98 \%$ of all 16 SrRNA sequences were well covered, indicating that the sampling intensity was sufficient to identify the bacteria present in all soil samples.

When grouped at the $97 \%$ similarity level, there were 16,206 (mean 10,665) different phylotypes for the soils. The dominant bacterial phyla across all of the soil samples were Proteobacteria, Firmicutes, Acidobacteria, Chloroflexi, and Verrucomicrobia (relative abundance $>3.5 \%$; Fig. 1a). Among the dominant bacterial phyla, the distribution of Proteobacteria, Firmicutes and Verrucomicrobia was closely related to calcareous soil type (Fig. 1). The relative abundance of Proteobacteria and Firmicutes was high in YCS and RCS but low 
Table 2. Bacterial diversity in soils derived from YCS, RCS and BCS.

\begin{tabular}{|c|c|c|c|c|c|c|c|c|}
\hline & & $\begin{array}{c}\text { Goods_cov- } \\
\text { erage }(\%)\end{array}$ & $\begin{array}{l}\text { Obtained } \\
\text { sequences }\end{array}$ & $\begin{array}{l}\text { Observed_ } \\
\text { OTUs }\end{array}$ & Simpson & Chaol & Shannon & $\begin{array}{l}\text { Abundance } \\
\left(10^{9} \text { copies g }^{-1}\right. \\
\text { soil })\end{array}$ \\
\hline \multirow[t]{6}{*}{ YCS } & Topsoil & $97.8 \pm 0.07 b$ & $94462 \pm 2742 b$ & $5071 \pm 587 \mathrm{a}$ & $0.99 \pm 0.004 \mathrm{a}$ & $6967 \pm 279 a$ & $9.45 \pm 0.55 \mathrm{a}$ & $9.18 \pm 1.53 \mathrm{a}$ \\
\hline & $0-20 \mathrm{~cm}$ & $97.8 \pm 0.07 \mathrm{C}$ & $5767 \pm 2579 \mathrm{C}$ & $5071 \pm 587 \mathrm{~A}$ & $0.99 \pm 0.004 \mathrm{~A}$ & $6967 \pm 279 A$ & $9.45 \pm 0.55 \mathrm{~A}$ & $4.88 \pm 2.87 \mathrm{~A}$ \\
\hline & $20-40 \mathrm{~cm}$ & $97.9 \pm 0.1 \mathrm{C}$ & $9012 \pm 4030 \mathrm{BC}$ & $4542 \pm 385 \mathrm{~A}$ & $0.99 \pm 0.005 \mathrm{~A}$ & $6570 \pm 366 \mathrm{~A}$ & $8.77 \pm 0.41 \mathrm{~A}$ & $2.55 \pm 0.81 \mathrm{AB}$ \\
\hline & $40-60 \mathrm{~cm}$ & $98.3 \pm 0.1 \mathrm{~B}$ & $9510 \pm 4253 \mathrm{BC}$ & $3542 \pm 405 \mathrm{AB}$ & $0.98 \pm 0.008 \mathrm{~A}$ & $5358 \pm 503 B$ & $7.87 \pm 0.61 \mathrm{AB}$ & $1.43 \pm 0.88 \mathrm{AB}$ \\
\hline & $60-80 \mathrm{~cm}$ & $98.5 \pm 0.1 \mathrm{AB}$ & $7651 \pm 3421 \mathrm{BC}$ & $2948 \pm 421 B$ & $0.97 \pm 0.012 \mathrm{~A}$ & $4643 \pm 446 \mathrm{BC}$ & $7.08 \pm 0.70 \mathrm{AB}$ & $0.28 \pm 0.11 \mathrm{~B}$ \\
\hline & $80-100 \mathrm{~cm}$ & $98.6 \pm 0.008 \mathrm{~A}$ & $9469 \pm 4234 \mathrm{~A}$ & $2758 \pm 245 B$ & $0.96 \pm 0.011 \mathrm{~A}$ & $4241 \pm 296 \mathrm{BC}$ & $6.83 \pm 0.55 \mathrm{~B}$ & $0.28 \pm 0.14 \mathrm{~B}$ \\
\hline \multirow[t]{6}{*}{$\mathrm{RCS}$} & Topsoil & $98.7 \pm 0.09 a$ & $114017 \pm 5087 \mathrm{a}$ & $2651 \pm 267 b$ & $0.96 \pm 0.009 \mathrm{a}$ & $4098 \pm 240 \mathrm{~b}$ & $6.56 \pm 0.49 b$ & $4.47 \pm 1.11 \mathrm{~b}$ \\
\hline & $0-20 \mathrm{~cm}$ & $98.3 \pm 0.16 \mathrm{~A}$ & $116191 \pm 4806 \mathrm{~A}$ & $3651 \pm 462 \mathrm{~A}$ & $0.98 \pm 0.004 \mathrm{~A}$ & $5349 \pm 539 \mathrm{~A}$ & $8.20 \pm 0.45 b$ & $3.2 \pm 1.09 \mathrm{~A}$ \\
\hline & $20-40 \mathrm{~cm}$ & $98.6 \pm 0.09 \mathrm{~A}$ & $109638 \pm 2539 \mathrm{~A}$ & $2709 \pm 243 \mathrm{AB}$ & $0.97 \pm 0.008 \mathrm{~A}$ & $4196 \pm 320 \mathrm{AB}$ & $7.16 \pm 0.52 \mathrm{~A}$ & $2.3 \pm 0.82 \mathrm{~A}$ \\
\hline & $40-60 \mathrm{~cm}$ & $98.8 \pm 0.13 \mathrm{~A}$ & $111621 \pm 7085 \mathrm{~A}$ & $2163 \pm 370 \mathrm{~B}$ & $0.96 \pm 0.013 \mathrm{~A}$ & $3531 \pm 457 \mathrm{~B}$ & $6.39 \pm 0.72 \mathrm{AB}$ & $1.2 \pm 0.69 \mathrm{AB}$ \\
\hline & $60-80 \mathrm{~cm}$ & $98.9 \pm 0.13 \mathrm{~A}$ & $105893 \pm 5718 \mathrm{~A}$ & $1969 \pm 403 \mathrm{~B}$ & $0.95 \pm 0.011 \mathrm{~A}$ & $3271 \pm 462 \mathrm{~B}$ & $6.04 \pm 0.67 \mathrm{AB}$ & $0.94 \pm 0.82 \mathrm{AB}$ \\
\hline & $80-100 \mathrm{~cm}$ & $98.9 \pm 0.2 \mathrm{~A}$ & $109823 \pm 6301 \mathrm{~A}$ & $1934 \pm 523 B$ & $0.94 \pm 0.012 \mathrm{~A}$ & $3323 \pm 658 \mathrm{~B}$ & $5.63 \pm 0.67 \mathrm{~B}$ & $0.96 \pm 0.07 \mathrm{~B}$ \\
\hline $\mathrm{BCS}$ & Topsoil & $97.8 \pm 0.03 b$ & $119493 \pm 6036 a$ & $4984 \pm 173 a$ & $0.99 \pm 0.001 \mathrm{a}$ & $7106 \pm 63 a$ & $8.89 \pm 0.11 \mathrm{a}$ & $4.02 \pm 0.64 \mathrm{~b}$ \\
\hline
\end{tabular}

The values of $0-20,20-40,40-60,60-80$, and $80-100 \mathrm{~cm}$ indicate the sampling depth in the profile.

Values are the means of replicates with their associated standard errors; means in a column with the same lowercase letters are not significantly different at the $p<0.05$ level in different soil types.

Means in a column with the same capital letters are not significantly different at the $p<0.05$ level along the profile in the same soil type.

in BCS. However, the trend in Verrucomicrobia relative abundance was the opposite. Additionally, the relative abundance of Chloroflexi was relatively steady throughout the profile. Along the YCS and RCS profiles, Proteobacteria and Firmicutes relative abundances increased, while those of Acidobacteria and Verrucomicrobia decreased.

The dominant bacterial genera across all of the soil samples were Exiguobacterium, Enterobacter and Acinetobacter (relative abundance $>1 \%$; Fig. 1b). The relative abundance of Exiguobacterium and Enterobacter were lower in YCS than that in RCS, while Acinetobacter relative abundance was not different between these two calcareous soils. Additionally, the relative abundance of Exiguobacterium, Enterobacter and Acinetobacter increased across the profile.

Twenty-four dominant bacterial OTUs (relative abundance $>0.5 \%$; Fig. 2) were highly abundant in 70 soils. Among them, half of the OTUs belonged to Proteobacteria strains. Strains of Firmicutes, Actinomadura and Chloroflexi were also frequently observed. Some of the bacterial sequences across 70 soils could not be classified into known species. Of these dominant OTUs (OTUs 14349, 3840, 8461, 3, 5731, 6066, 7, 5, 6, 6667 and 4) and OTUs (2, 2754, 2653 and 1) differed significantly among profiles, and corresponded to Proteobacteria and Firmicutes species, respectively (Fig. 2). OTUs 11, 9664, and 12000 were most abundant in BCS. OTUs 43 and 14 were most abundant in RCS. OTUs 14349, 3840, 8461, 3, 5731, $6066,7,2,5,6,6667,4,2754,2653$ and 1 increased across the profile, while OTUs 13, 12456, 7360, 9, 43 and 14 decreased.

The SOC and TN contents were closely correlated with the abundances of some bacterial groups (Table 3). The abundances of Proteobacteria and Firmicutes exhibited a highly significant negative correlation with SOC and TN, while the abundances of Actinobacteria, Planctomycetes, Bacteroidetes and Nitrospirae exhibited a markedly positive correlation with SOC, TN. The abundance of Chloroflexi had a significant negative correlation with SOC but had no correlation with TN.

Soil $\mathrm{pH}$ was also closely related to the abundances of some bacterial groups (Table 3). The relative abundances of Proteobacteria, Firmicutes, Thaumarchaeota and Nitrospirae were significantly positively correlated with soil $\mathrm{pH}$, while those of Acidobacteria, and Chloroflexi were negatively correlated with soil $\mathrm{pH}$. The abundances of other bacterial groups had no significant correlation with soil $\mathrm{pH}$.

\section{Bacterial Community Diversity}

To compare the soil bacterial community diversity among soils, we randomly selected 80,574 sequences from each sample. The results revealed that the number of observed OTUs (at the 97\% similarity level) ranged 


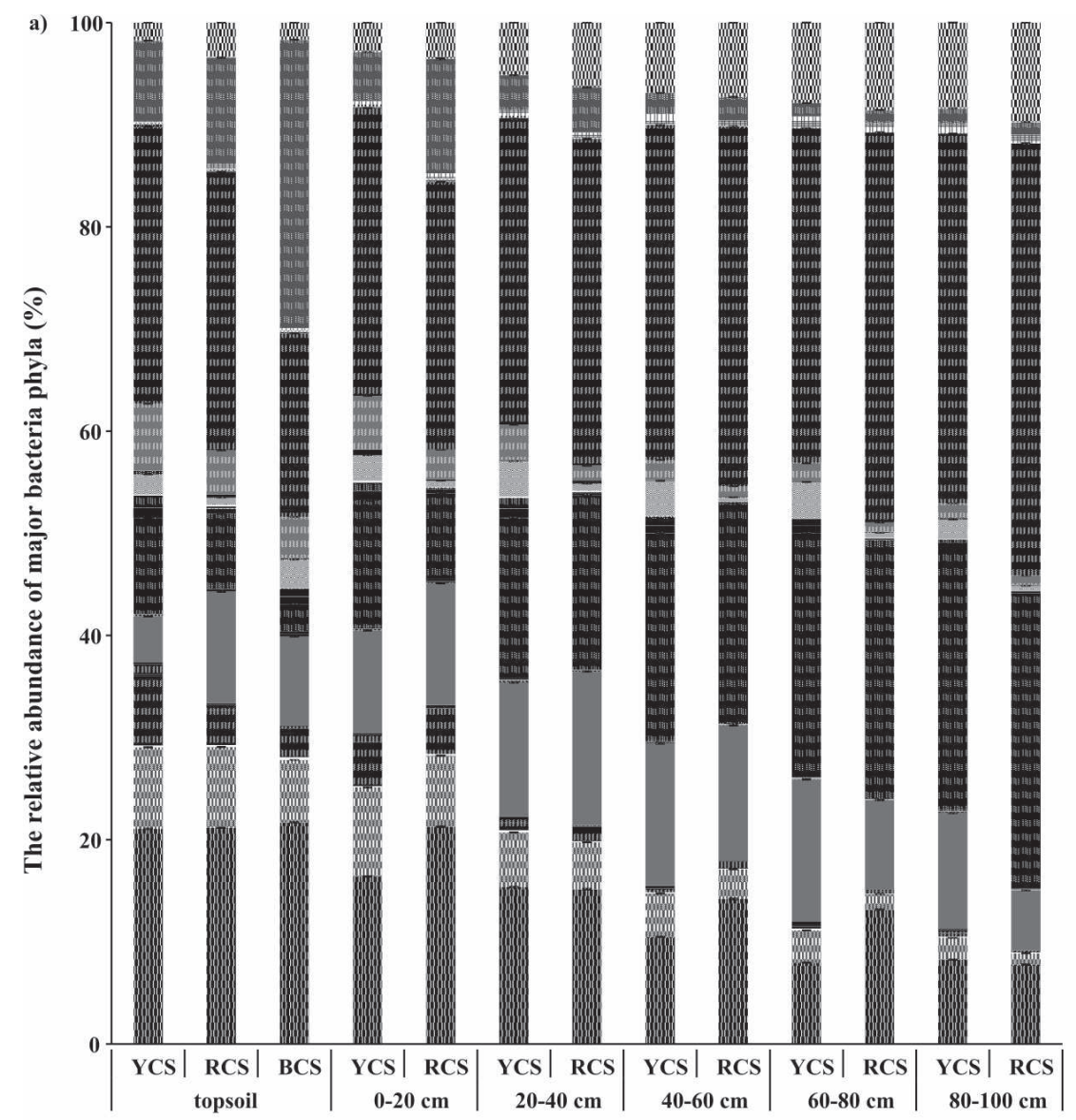

w Unclassified

m. WD272

14. WCHB1-60

m Verrucomicrobia

\# Thermotogae

Tenericutes

in TM6

10. Synergistetes

- Spirochaetae

- Saccharibacteria

u SM2F11

mI SHA-109

m Proteobacteria

- Planctomycetes

a Parcubacteria

m Omnitrophica

- Nitrospirae

Microgenomates

- Lentisphaerae

m Latescibacteria

m. JL-ETNP-Z39

- Hydrogenedentes

\# Gracilibacteria

\# Gemmatimonadetes

m GOUTA4

GAL08

IIII Fusobacteria

m Firmicutes

m Fibrobacteres

- Elusimicrobia

Deinococcus-Thermus

를 Deferribacteres

-manobacteria

- Chloroflexi

- Chlorobi

- Chlamydiae

- Candidate division OP3

w Bacteroidetes

Atribacteria

Armatimonadetes

- Aerophobetes

Actinobacteria

in Acidobacteria

- Acetothermia

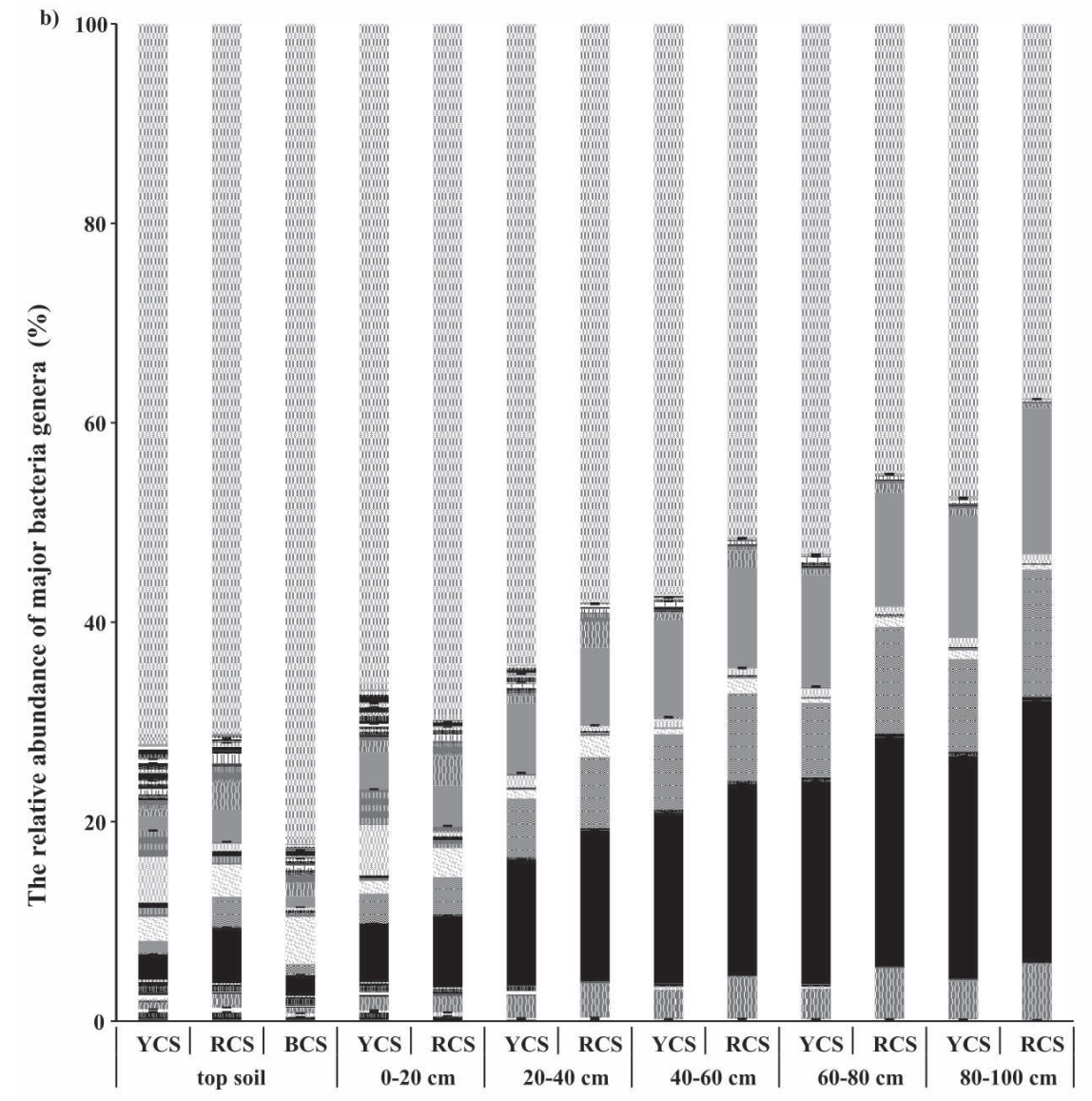

(แI) Unclassified

(w) Ferruginibacter

: Gemmata

= Mycobacterium

"Pedomicrobium

w Pirellula

mi Reyranella

Steroidobacter

Ferruginibacter

w. Pedomicrobium

m Pirellula

"Aquicella

Bryobacter

- Chthoniobacter

Nitrospira

|| Rhizomicrobium

-moseiflexus

m Variibacter

㽗 Variovorax

In Acidibacter

InI Acidothermus

- Acinetobacter

- Arthrobacter

Bacillus

- Bradyrhizobium

inin Burkholderia

Candidatus Accumulibacter

- Enterobacter

- Enterococcus

- Exiguobacterium

miv. Flavisolibacter

Flavobacterium

maliangium

Opitutus

Ornatilinea

II Planctomyces

. Sorangium

- Sphingomonas

- Streptomyces

Fig. 1. Relative abundances of bacterial phyla a) and genera b) in soils derived from YCS, RCS and BCS. The relative abundances are given as percentages of the total classified 16S rRNA gene sequences in each of the dominant phyla and genera. 


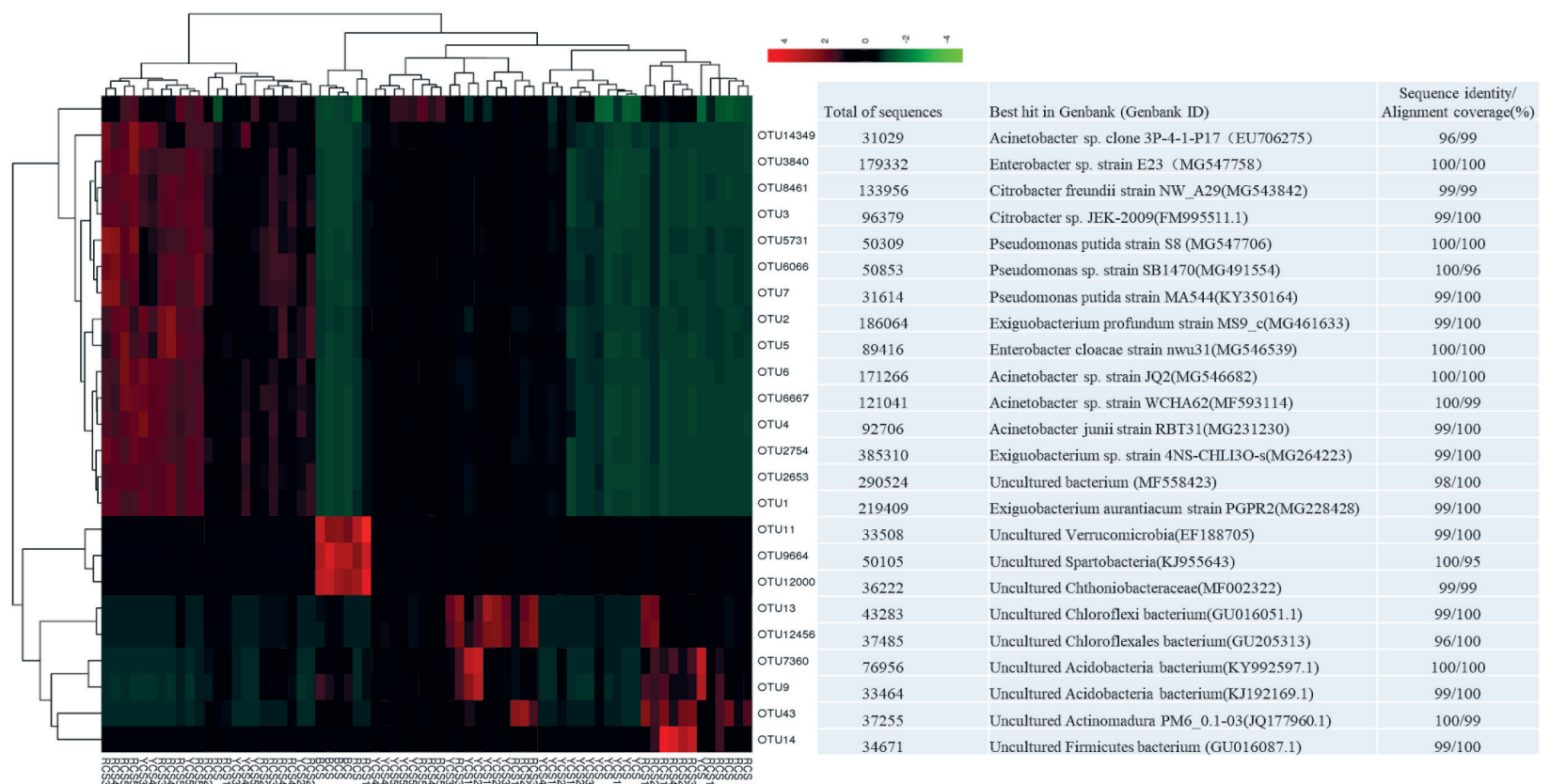

Fig. 2. Heatmap of the relative abundances of dominant OTUs that were found to differ significantly across profiles in karst calcareous soils.

from 1934 to 5070 across the 70 soils (Table 2). Based on the number of OTUs observed in each soil, the Chaol estimator ranged from 3323 to 7106 OTUs, and the coverage ranged from $97.8 \%$ to $98.9 \%$ (Table 2), indicating that the sequencing depth was sufficient for this study.
The diversity of the bacterial communities was clearly different among the observed soils. The values of bacterial Shannon-Wiener diversity indices and Chaol estimators and the number of observed OTUs were higher in YCS and BCS than in RCS. Simultaneously, a high diversity (including the indices of Shannon-

Table 3. Pearson's correlations between the numbers of bacterial OTUs collapsed at the species level, Chaol estimator, and Simpson and Shannon's indices and the soil properties.

\begin{tabular}{|c|c|c|c|c|c|c|c|c|c|c|}
\hline & \multicolumn{2}{|c|}{ SOC } & \multicolumn{2}{|c|}{ AP } & \multicolumn{2}{c|}{$\mathrm{pH}$} & \multicolumn{3}{c|}{ TN } & \multicolumn{2}{c|}{ TP } \\
\hline & $\mathrm{r}$ & $\mathrm{p}$ & $r$ & $p$ & $r$ & $p$ & $r$ & $p$ & $r$ & $p$ \\
\hline Proteobacteria & -0.49 & 0.00 & -0.34 & 0.00 & 0.28 & 0.02 & -0.46 & 0.00 & -0.39 & 0.00 \\
\hline Firmicutes & -0.38 & 0.00 & -0.36 & 0.00 & 0.33 & 0.00 & -0.32 & 0.01 & -0.30 & 0.01 \\
\hline Acidobacteria & & & & & -0.47 & 0.00 & & & & \\
\hline Chloroflexi & -0.25 & 0.03 & & & -0.44 & 0.00 & & & & \\
\hline Verrucomicrobia & & & & & & & 0.46 & 0.00 & 0.71 & 0.00 \\
\hline Actinobacteria & 0.61 & 0.00 & 0.52 & 0.00 & & & 0.59 & 0.00 & 0.26 & 0.03 \\
\hline Planctomycetes & 0.71 & 0.00 & 0.71 & 0.00 & & & 0.70 & 0.00 & 0.32 & 0.01 \\
\hline Thaumarchaeota & & & 0.29 & 0.02 & 0.24 & 0.04 & 0.29 & 0.02 & \\
\hline Bacteroidetes & 0.62 & 0.00 & 0.67 & 0.00 & & & 0.58 & 0.00 & 0.29 & 0.01 \\
\hline Nitrospirae & 0.41 & 0.00 & 0.32 & 0.01 & 0.55 & 0.00 & 0.54 & 0.00 & & \\
\hline Chaol estimator & 0.65 & 0.00 & 0.58 & 0.00 & & & 0.64 & 0.00 & 0.47 & 0.00 \\
\hline Shannon-Wiener diversity index & 0.52 & 0.00 & 0.52 & 0.00 & & & 0.50 & 0.00 & 0.31 & 0.00 \\
\hline Simpson's index & 0.39 & 0.00 & 0.41 & 0.00 & & & 0.38 & 0.00 & 0.25 & 0.04 \\
\hline Bacterial abundance & 0.76 & 0.00 & 0.65 & 0.00 & & & 0.73 & 0.00 & 0.34 & 0.00 \\
\hline Number of observed OTUs & 0.64 & 0.00 & 0.58 & 0.00 & & & 0.61 & 0.00 & 0.44 & 0.00 \\
\hline
\end{tabular}


Table 4. Significance tests using the nonparametric multivariate statistical approaches (ADONIS and MRPP) to assess the effects of the soil type on the bacterial community structure.

\begin{tabular}{|c|c|c|c|c|c|c|}
\hline \multirow{2}{*}{ Comparisions } & \multicolumn{3}{|c|}{ ADONIS } & \multicolumn{3}{c|}{ MRPP } \\
\cline { 2 - 7 } & $R^{2}$ & F & $P$ & Observed $\delta$ & Expected $\delta$ & $P$ \\
\hline YCS vs BCS & 0.345 & 3.683 & $\mathbf{0 . 0 1 9}^{*}$ & 0.466 & 0.579 & $\mathbf{0 . 0 1}^{*}$ \\
\hline YCS vs RCS & 0.198 & 2.216 & 0.073 & 0.624 & 0.666 & 0.074 \\
\hline BCS vs RCS & 0.2878 & 3.235 & $\mathbf{0 . 0 4 1}^{*}$ & 0.481 & 0.574 & $\mathbf{0 . 0 2 2}^{*}$ \\
\hline
\end{tabular}

The difference is significant when at least two tests gave $P$ values of $<0.05$ (bold ${ }^{*}$ ).

Wiener diversity, the number of observed OTUs and the value of Chaol estimator) of bacterial communities was found in the topsoil, but these communities became similar at depths below $40 \mathrm{~cm}$. The bacterial Simpson's index appeared to be similar among three calcareous soil types and two soil profiles.

Of the soil characteristics that were considered, we found that the SOC content was significantly positively correlated with the bacterial Shannon-Wiener diversity, the number of observed OTUs, Simpson's index and Chaol estimator. The AP content exhibited positive relationships with the bacterial ShannonWiener diversity, the number of observed OTUs, Simpson's index and Chaol estimator. The TN content was related to the bacterial Shannon-Wiener diversity, the number of observed OTUs, Simpson's index and Chaol estimator. The TP content was significantly positively correlated with the bacterial Shannon-Wiener diversity, the number of observed OTUs, and Chaol estimator).

\section{Linking Edaphic Properties, Taxonomic Distribution and Bacterial Community Structure}

ADONIS and MRPP analysis for the community structure comparison showed that bacterial community structure in BCS significantly differed from that in YCS and RCS, while there was no change in the bacterial community structure between YCS and RCS (Table 4).

RDA indicated that the soil TN ( $p=0.001, \mathrm{~F}=15.2)$, SOC $(p=0.001, \mathrm{~F}=13.4), \mathrm{pH}(p=0.001, \mathrm{~F}=12.4)$, $\mathrm{AP}(p=0.001, \mathrm{~F}=9.1)$ and $\mathrm{TP}(p=0.001, \mathrm{~F}=4.7)$ contributed remarkably to the distribution of bacterial community compositions. These variables explained $29 \%$ of the variance in the bacterial community compositions (Fig. 3).

Path analysis showed that SOC and TN contents had a direct effect on soil bacterial composition. Soil type and profile indirectly affected soil bacterial composition through SOC and TN contents. Simultaneously, calcareous soil type can directly influence soil bacterial composition (Fig. 4).

\section{Discussion}

\section{Bacterial Community Composition in the Karst Calcareous Soils}

In the present study, it has been observed that bacterial communities in karst topsoils were dominated by Acidobacteria, Proteobacteria, and Actinobacteria, similar to the trends of bacterial communities in topsoils of Northeast China [19] and South Moravia [20]. In contrast, the relative average abundance of Verrucomicrobia in karst topsoils was nearly 5\% (Fig. 1), which is twice as high as the Verrucomicrobia abundances reported by Wang et al. [19] and SagovaMareckova et al. [20] (less than 2\%). The soil samples in those studies were collected from non-karst regions. The karst region is specialized, having high proportions

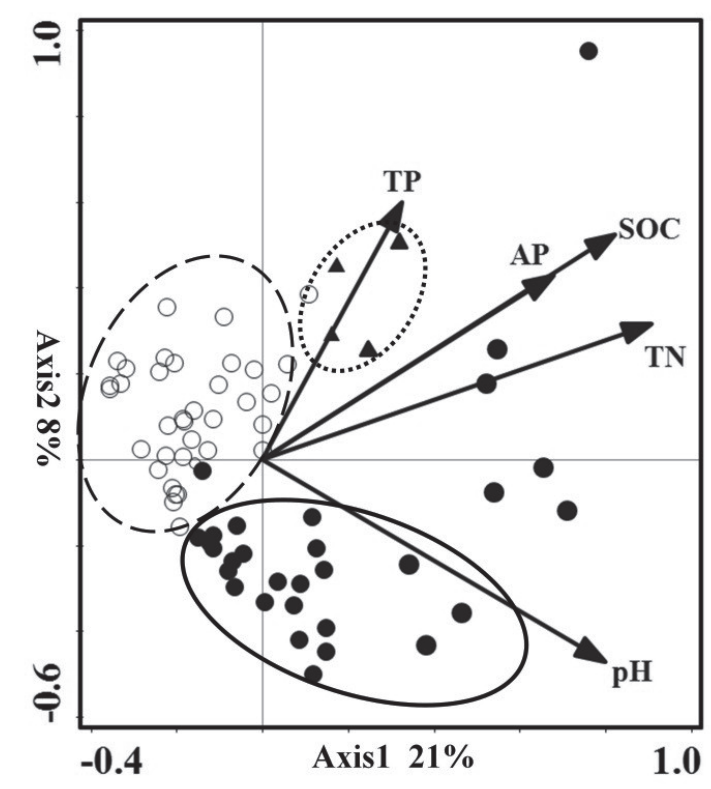

Fig. 3. Redundancy analysis of bacterial community structure in different soil types across the profile from the karst shrub ecosystem. Arrows represent environmental variables. Open circle, red calcareous soil; solid triangle, black calcareous soil; solid circle, yellow calcareous soil. SOC, soil organic carbon; $\mathrm{TN}$, total nitrogen; AP, available phosphorus; and TP, total phosphorus. 


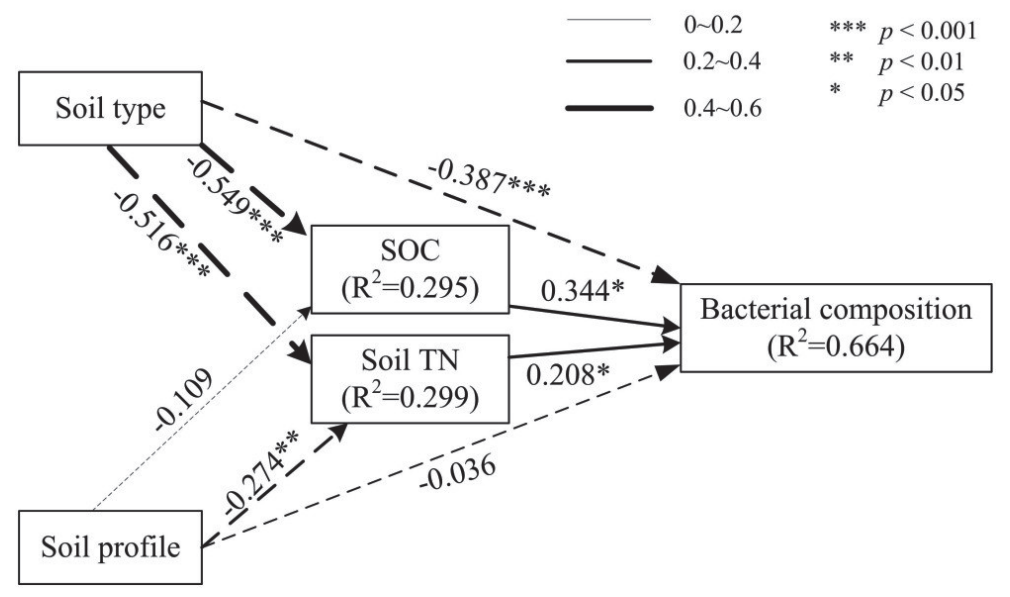

Fig. 4. Path model of direct and indirect effects of soil properties on bacterial composition in karst calcareous soils. Each value associated with an arrow is a path coefficient and is equivalent to the direct effect of the independent variable on the dependent variable. The width of the arrows indicates the strength of the standardized path coefficient. The solid lines indicate positive path coefficients and dashed lines indicate negative path coefficients.

of rocky exposure, and alkaline calcareous soils [2]. The soil samples in this study were collected from karst regions, suggesting that the bacterial community compositions in karst calcareous soils might be altered by the typical vegetation in these soils and their high $\mathrm{Ca}$ and $\mathrm{Mg}$ contents.

Proteobacteria have been previously detected at high abundance in many soils $[5,6,21]$, and most of their species have copiotrophic lifestyles [22]. However, a negative correlation between the abundance of Proteobacteria and SOC content $(p<0.001)$ was observed in the present study, in agreement with the results reported by Liu et al. [23]. These results may be related to the ecosystem function of this phylum. The Proteobacteria phyla included Alpha-, Beta-, and Gammaproteobacteria. Species belonging to Betaproteobacteria preferentially utilize easily accessible carbon [24]. Alphaproteobacteria preferentially utilize polycyclic aromatic hydrocarbons [25]. This contrast highlights that Proteobacteria species possess differing abilities to use carbon sources and thus play a key role in carbon recycling. Therefore, the higher abundance of Proteobacteria suggests that deep soils from eroded and redeposited soils represent a carbon sink [26].

In addition, the oligotrophic phylum Verrucomicrobia is ubiquitous in soil [27]. In the present study, the abundance of Verrucomicrobia and TP content were correlated (Table 3). Our results were consistent with the findings reported by Wang et al. [19] but not with hose reported by Qiu et al. [28]. This inconsistency was closely related to this bacterial phylum, which likely occupies different ecological niches in soils [29]. Interestingly, Verrucomicrobia are likely to be far more abundant in the present soil than in soils from previous studies, suggesting (as most of the commonly used 'universal' bacterial primers are biased against Verrucomicrobia) [30] that the ecological niches inhabited by soil Verrucomicrobia remain largely undetermined and that the few cultured isolates representing those verrucomicrobial taxa are thus most commonly found in soils [30]. Therefore, the ecological relevance of this bacterial phylum, which is dominant in the subsurface soils in karst regions, is still less known and is needed to study in future works.

\section{Soil Type as the Major Factor in Determining Bacterial Communities}

RDA clearly demonstrated that the bacterial communities were separated into YCS, RCS and $\mathrm{BCS}$, suggesting that calcareous soil type is the major factor in determining the bacterial communities in karst regions (Fig. 3). This result was consistent with the previous reports [14]. Soil type alters microbial communities mainly through soil properties. We found that bacterial communities changed synchronously with the soil properties of three calcareous soil types, such as their organic matter content and $\mathrm{pH}$ values (Fig. 3). Additionally, the distribution patterns of bacterial in three calcareous soils indicated that the RCS group was more tightly clustered than the YCS group, suggesting that the bacterial communities were more stable in RCS. Interestingly, the relative abundances of Proteobacteria and Firmicutes were high in YCS and RCS but low in BCS. However, the trends in Verrucomicrobia relative abundances in these three calcareous soils were the opposite. This bacterial phylum did not show consistent shifts in relative abundance among three calcareous soil types, suggesting specific microbial community characteristics in different calcareous soil types. The distributions of Proteobacteria, Firmicutes and Verrucomicrobia were closely related to calcareous soil types (Fig. 1) and were sensitive to changes in soil quality. 


\section{Succession of Bacterial Communities along the Soil Profiles}

Soil depth is also a key factor influencing the bacterial community structure [31, 32]. Many previous studies have indicated that soil microbial communities in subsurface environments are distinct from surface communities [28], which agree with the results of our present study. This observation can be explained by several phenomena. First, the greater variability in soil bacterial communities across the profile is likely a product of the greater variability in edaphic factors (i.e., SOC and TN; Fig. 1). Second, environmental factors, particularly differences in temperature and moisture, caused the differentiation of bacterial communities across soil profiles [19]. Furthermore, the influences of plant species on microbial community structure may be more apparent in surface horizons, where shrub root densities and litter inputs are abundant. Altogether, environmental conditions, including soil depth, represent a strong ecological filter, and many surfacedwelling microorganisms are less likely to thrive in the environments of the deeper soil horizons, as seen in Fig. 1.

Across all soil profiles, Proteobacteria and Acidobacteria were the most abundant phyla, which is generally consistent with findings of other studies, i.e., that soils often contain these two ubiquitous and common bacterial groups [33]. Many Proteobacteria species are considered R-strategists, i.e., fast-growing bacteria that are most abundant in nutrient-rich environments [5, 22], and are copiotrophic. However, Acidobacteria species are considered K-strategists i.e., slow-growing bacteria that typically have a high affinity for growth with limited resources, and are oligotrophic (Fig. 1). Therefore, the change from Acidobacteria dominance to Proteobacteria dominance with soil depth suggests that belowground communities have transitioned from slow-growing oligotrophic groups to fast-growing copiotrophic groups in calcareous soils.

\section{Relationship between Soil Properties and Bacterial Communities}

A previous study reported that soil properties, including SOC, TN, and TP, varied among different calcareous soils in karst regions in Northeast China [4]. However, the soil microbes were not described in that paper. In this study, we collected 70 calcareous soil samples from the karst region and found that the SOC and TN contents as well as the bacterial communities greatly changed, and the SOC and TN contents had a strong influence on very positive relationships with the soil bacterial communities in calcareous soils. However, the largest difference among the $\mathrm{pH}$ values of the tested soils was only $1.96 \mathrm{pH}$ units (Table 1). Therefore, we concluded that the SOC and TN contents might have stronger influences than the soil $\mathrm{pH}$ on shifting the distribution of soil bacterial communities among different calcareous soils.

The RDA in this study indicated that the SOC content was a key factor influencing the soil bacterial community composition (Fig. 3). The relative abundances of four bacterial groups, Acidobacteria, Verrucomicrobia, Proteobacteria and Firmicutes, had significant negative or positive relationships with SOC contents in calcareous soils (Table 3). These results were in agreement with many previous studies that SOC content is a major factor determining soil bacterial diversity and composition. For example, a previous study has discovered that SOC content was the most important factor in shaping the soil bacterial community structures in a tropical agricultural soil [9]. Lian et al. reported that Actinobacteria abundance was markedly enriched in SOC-poor soil [6], while Yan et al. [5] found that Proteobacteria abundance was markedly enriched in SOC-rich soil. Additionally, with regard to subgroups within a single phylum, Sul et al. found that Acidobacteria subgroups 1 and 7 were more abundant in low-SOC plots than were other Acidobacteria subgroups, whereas Acidobacteria subgroups 4 and 6 were more abundant in high-SOC plots [34]. Thus, the response of soil bacteria to SOC content is not uniform, and this variation depends on the specific functions of species or other soil properties.

In addition to SOC content, other soil properties such as $\mathrm{pH}$ were also correlated with bacterial community structure (Table 3, Fig. 3), which agrees with previous studies. For example, the relative abundance of Acidobacteria increases with decreasing $\mathrm{pH}[12,35]$. In this study, the relative abundance of Chloroflexi decreased at higher $\mathrm{pH}$ values in this study, which contrasts with results in a previous study [36]. Significant correlations were also observed between soil $\mathrm{pH}$ and the relative abundances of the less dominant phyla (Table 3) such as Nitrospirae and Thaumarchaeota, which had low abundances, indicating that the effect of $\mathrm{pH}$ is still apparent when rarer members of the community are assessed. The ecological mechanisms for this relationship are complicated. In karst regions, calcareous soil forms a thin black calcareous soil, after weathering, forms yellow calcareous soil and ultimately red calcareous soil. Mineral weathering, especially for weathering of $\mathrm{Ca}$ carbonates, may facilitate soil acidification. Soil acidification influences bacterial survival [37] because most bacterial taxa have a relatively narrow $\mathrm{pH}$ range for their growth. Thus, the biggest difference in soil $\mathrm{pH}$ was only $1.96 \mathrm{pH}$ units and the SOC and TN contents were quite different among the 70 soils, the bacterial community composition, abundance and diversity were significantly correlated with the soil $\mathrm{pH}$ (Table 3; Fig. 3). Therefore, our results further emphasized that soil $\mathrm{pH}$ also plays an important role in shaping the bacterial community composition in karst calcareous soils. 


\section{Conclusions}

Illumina HiSeq sequencing techniques revealed that the calcareous soils are dominated by Proteobacteria, Firmicutes, Acidobacteria, Chloroflexi, and Verrucomicrobia. The relative abundances of Proteobacteria, Firmicutes and Verrucomicrobia were closely associated with calcareous soil types. RDA demonstrated a separation of bacterial community structures among calcareous soil types, and the impact of yellow calcareous soil in shaping the communities was greater than that of red calcareous soil. The consistency among bacterial communities changed with the soil profiles, and the community clearly transitioned from being Acidobacteria dominant to Proteobacteria dominant with depth. Notably, SOC content was a key factor in shaping bacterial community structure in calcareous soils. Proteobacteria species might play an important role in the carbon cycle and were found with high abundance in deep soils, suggesting that deep soils generated from eroded and redeposited soils represent a carbon sink in karst calcareous soils. Much more studies will be needed to confirm this possibility.

\section{Acknowledgements}

The authors give special thanks to Prof. Meiliang Zhang for his invaluable assistance in sample collection and Guangxi Key Laboratory of Environment Pollution Control Theory and Technology for Science and Education Combined with Science and Technology Innovation Base for providing the experiment platform. This project was supported by the Science and Technology Major Project of Guangxi (grant number AA17204087-7), the National Natural Science Foundation of China (grant numbers 31800441 and 41907208), the Natural Science Foundation of Guangxi (grant numbers 2017GXNSFAA198241, 2018GXNSFBA138012), the Foundation of Key Laboratory of Karst Dynamics, MNR \& GZAR (grant number KDL201803), and Guangxi Key Science and Technology Innovation Base on Karst Dynamics (KDL\&Guangxi 202004).

\section{Conflict of Interest}

The authors declare no conflict of interest.

\section{References}

1. YUAN D. Geology and Geohydrology of Karst and its Relevance to Society, The $30^{\text {th }}$ Session of IGCP Scientific Board. UN ESCO, Paris, 15, 2002.

2. CLARHOLM M., SKYLlBERG U., ROSLING A. Organic acid induced release of nutrients from metalstabilized soil organic matter-Theunbutton model. Soil Biol. Biochem. 84, 168, 2015.
3. LIU Y.G., LIU C.C., WANG S.J., GUO K., YANG J., ZHANG X.S., LI G.Q. Organic carbon storage in four ecosystem types in the karst region of southwestern China. PLOS One. 8 (2), e56443, 2013.

4. ZHANG M.L., DENG Z.Q. The soil and soil-forming processed in karst area of south China. J. Guizhou. I. Technology. 23, 67, 1994 [In Chinese].

5. YAN B.S., SUN L.P., LI J.J., LIANG C.Q., WEI F.R., XUE S., WANG G.L. Change in composition and potential functional genes of soil bacterial and fungal communities with secondary succession in Quercus liaotungensis forests of the Loess Plateau, western China. Geoderma, 364, 114199, 2020.

6. LIAN T.X., JIN J., WANG G.H., TANG C.X., YU Z.H., LI Y.S., LIU J.J., ZHANG S.Q., LIU X.B. The fate of soybean residue-carbon links to changes of bacterial community composition in Mollisols differing in soil organic carbon. Soil Biol. Biochem. 109, 50, 2017.

7. ZHAO F.Z., BAI L., WANG J.Y., DENG J., REN C.J., HAN X.H., YANG G.H., WANG J. Change in soil bacterial community during secondary succession depend on plant and soil characteristics. Catena, 173, 246, 2019.

8. LIANG Y.M., PAN F.J., HE X.Y., CHEN X.B., SU Y.R. Effect of vegetation types on soil arbuscular mycorrhizal fungi and nitrogen-fixing bacterial communities in a karst region. Environ. Sci. Pollut. R. 23 (18), 18482, 2016.

9. ZHANG C., LI J., WANG J., LIU G.B., WANG G.L., GUO L., PENG S.Z. Decreased temporary turnover of bacterial communities along soil depth gradient during a 35 -year grazing exclusion period in a semiarid grassland. Geoderma, 351, 49, 2019.

10. BAI R., WANG J.T., DENG Y., HE J.Z., FENG K., ZHANG L.M. Microbial community and functional structure significantly varied among distinct types of paddy soils but responded differently along gradients of soil depth layers. Front. Microbiol. 8, 945, 2017.

11. WAN W.J., TAN T., WANG J.D., QIN Y., HE H.G., WU H.Q., ZUO E.L., HE D.G. Responses of the rhizosphere bacterial community in acidic crop soil to $\mathrm{pH}$ : Changes in diversity, composition, interaction, and function. Sci Total Environ. 700, 134418, 2020.

12. SHEN C.C., SHI Y., FAN K.K., HE J.S., ADAMS J.M., GE Y., CHU H.Y. Soil pH dominants elevational diversity pattern for bacteria in high elevation alkaline soils on the Tibetan Plateau. Fems. Microbiol. Ecol. 95, 2, 2019.

13. ZHALNINA K., DIAS R., QUADROS P.D.D., DAVISRICHARDDSON A., CAMARGO F.A.O., CLARK I.M., MCGRATH S.P., HIRSCH P.R., TRIPLETT E.W. Soil pH Determines Microbial Diversity and Composition in the Park Grass Experiment. Microb. Ecol. 69, 395, 2015.

14. NICOLITCH O., COLIN Y., TURPAULT M.P., UROZ S. Soil type determines the distribution of nutrient mobilizing bacterial communities in the rhizosphere of beech trees. Soil Biol. Biochem. 103, 429, 2016.

15. VAN LEEUWEN J.P., DJUKIC I., BLOEM J., LEHTINEN T., HEMERIK L., DE RUITER P.C., LAIR G.J. Effects of land use on soil microbial biomass, activity and community structure at different soil depths in the Danube floodplain. Eur. J. Soil Biol. 79, 14, 2017.

16. COLWELL J.D. The estimation of phosphorus fertilizer requirements of wheat in southern New South Wales by soil analysis. Aust. J. Exp. Agric. Anim. Husb. 3, 190, 1963.

17. BREMNER J.M. Total nitrogen. In: Black CA (ed) Methods of soil analysis. American Society of Agricultural, USA, 2, 1149, 1956. 
18. CAPORASO J.G., BITTINGER K., BUSHMAN F.D., DESANTIS T.Z., ANDERSEN L., KNIGHT R. PyNAST: a flexible tool for aligning sequences to a template alignment. Bioinformatics, 26, 266, 2010.

19. WANG J., LIU G.B., ZHANG C., WANG G.L., FANG L.C., CUI Y.X. Higher temporal turnover of soil fungi than bacteria during long-term secondary succession in a semiarid abandoned farmland. Soil Till. Res. 194, 104305, 2019.

20. SAGOVA-MARECKOVA M., ZADOROVA T., PENIZEK V., OMELKA M., TEJNECKY V., PRUCHOVA P., CHUMAN T., DRABEK O., BURSOVA A., VANEK A., KOPECKY J. The structure of bacterial communities along two vertical profiles of a deep colluvial soil. Soil Biol. Biochem. 101, 65, 2016.

21. ZENG Q.C., AN S.S., LIU Y. Soil bacterial community response to vegetation succession after fencing in the grassland of China. Sci Total Environ. 609, 2, 2017.

22. ZHOU Z., WANG C., JIANG L., LUO Y. Trends in soil microbial communities during secondary succession. Soil Biol. Biochem. 115, 92, 2017.

23. LIU J.J., SUI Y.Y., YU Z.H., SHI Y., CHU H.Y., JIN J., LIU X.B. High throughput sequencing analysis of biogeographical distribution of bacterial communities in the black soils of northeast China. Soil Biol. Biochem. 70, 113, 2014.

24. PHILIPPOT L., TSCHERKO D., BRU D., KANDELER E. Distribution of high bacterial taxa across the chronosequence of two alpine glacier forelands. Microb. Ecol. 61, 303, 2011.

25. ARULAZHAGAN P., VASUDEVAN N., YEOM I.T. Biodegradation of polycyclic aromatic hydrocarbon by a halotolerant bacterial consortium isolated from marine environment. Int. J. Environ. Sci. Te. 7, 639, 2010.

26. VANDENBYGAART A.J., GREGORICH E.G., HELGASON B.L. Cropland C erosion and burial: is buried soil organic matter biodegradable? Geoderma, 239, 240, 2015.

27. ZHANG J.H., LI M, JIA K.L., ZHENG G.Q., LONG X.E. Seasonal variation rather than stand age determines bacterial diversity in the rhizosphere of wolfberry (Lycium barbarum L.) associated with soil degradation. J. Soil. Sediment. 18, 1518, 2018.

28. QIU J.M., CAO J.H., LANG G.Y., LIANG Y.M., WANG H., LI Q. The Influence of Land Use Patterns on Soil Bacterial Community Structure in the Karst Graben Basin of Yunnan Province, China. Forests, 11, 55, 2020.
29. CARSON C.M., ZEGLIN L.H. Long-term fire management history affects $\mathrm{N}$-fertilization sensitivity, but not seasonality, of grassland soil microbial communities. Soil Biol. Biochem. 121, 231, 2018.

30. BERGMANN G.T., BATES S.T., EILERS K.G., LAUBER C.L., CAPORASO J.G., WALTERS W.A., KNIGHT R., FIERER N. The under-recognized dominance of Verrucomicrobia in soil bacterial communities. Soil Biol. Biochem. 43, 1450, 2011.

31. YU H.L., LING N., WANG T.T., ZHU C., WANG Y., WANG S.J., GAO Q. Responses of soil biological t raits and bacterial communit ies to nitrogen fertilization mediate maize yields across three soil types. Soil Till. Res. 185, 61, 2019.

32. SENBAYRAM M ., SAYGAN E.P., CHEN R., AYDENIR S., KAYA C., WU D., BLADOGATSKAYA E. Effect of biochar origin and soil type on the greenhouse gas emission and the bacterial community structure in $\mathrm{N}$ fert ilised acidic sandy and alkal ine clay soil.Sci Total Environ. 660, 69, 2019.

33. ZHANG C., LIU G.B., XUE S., WANG G.L. Soil bacterial community dynamics reflect changes in plant community and soil properties during the secondary succession of abandoned farmland in the Loess Plateau. Soil Biol. Biochem. 97, 40, 2016.

34. SUL W.J., ASUMING-BREMPONG S., WANG Q., TOURLOUSSE D.M., PENTON, C.R., DENG Y., RODRIGUES J.L.M., ADIKU S.G.K., JONES J.W., ZHOU J.Z., COLE J.R., TIEDJE J.M. Tropical agricultural land management influences on soil microbial communities through its effect on soil organic carbon. Soil Biol. Biochem. 63, 33, 2013.

35. WU Y., ZENG J., ZHU Q., ZHANG Z., LIN X. pH is the primary determinant of the bacterial community structure in agricultural soils impacted by polycylic aromatic hydrocarbon pollution. Sci Rep-UK. 7, 40093, 2017.

36. YAO M.J., RUI J.P., NIU H.S. The differentiation of soil bacterial communities along a precipitation and temperature gradient in the eastern Inner Mongolia steppe. Catena, 152, 47, 2017.

37. SHEN C.C., SHI Y., FAN K.K., HE J.S., ADAMS J.M., GE Y., CHU H.Y. Soil pH dominants elevational diversity pattern for bacteria in high elevation alkaline soils on the Tibetan Plateau. FEMS Microbiol. Ecol. 95, 2, 2019. 